\title{
Recovery of skeletal elements and extended wing from a mounted specimen of the nearly extinct Slender-billed Curlew (Numenius tenuirostris)
}

\author{
Marco Pavia ${ }^{1}$, Giovanni Boano ${ }^{2 *}$
}

\begin{abstract}
The Slender-billed Curlew (Numenius tenuirostris) is a very rare Palaearctic Scolopacidae, classified Critically Endangered by the IUCN, with the last accepted record in 2001. In the museum collections, it is commonly preserved with mounted specimens and study skins, but only two skeletons have been reported in the world. Here we present the re-preparation of a mounted specimen from the collection of the Museo di Zoologia of the Torino University in order to obtain as much osteological material as possible. This practice, especially with rare or extinct species, is recommended in different papers to maximize the value of the museum specimens and remedy the lack of skeletal elements of very rare or extinct species.
\end{abstract}

Key words: Slender-billed Curlew, Numenius tenuirostris, skeletal elements.

Riassunto - Recupero di elementi scheletrici e ala distesa da un esemplare montato di chiurlottello (Numenius tenuirostris).

Il chiurlottello (Numenius tenuirostris) è uno Scolopacide paleartico molto raro, classificato come gravemente minacciato dalla IUCN, con l'ultima segnalazione accettata avvenuta nel 2001. Nelle collezioni dei musei è comunemente conservato con esemplari montati e pelli di studio, ma nel mondo sono stati segnalati solo due scheletri. Qui presentiamo la ri-preparazione di un esemplare montato dalla collezione del Museo di Zoologia dell'Università di Torino per ottenere quanto più materiale osteologico possibile. Questa pratica, in particolare con specie rare o estinte, è raccomandata in diversi articoli per massimizzare il valore degli esemplari museali e rimediare alla mancanza di elementi scheletrici di specie molto rare o estinte.

Parole chiave: chiurlottello, Numenius tenuirostris, elementi scheletrici.

Museo di Geologia e Paleontologia, Dipartimento di Scienze della Terra, Università degli Studi di Torino, Via Valperga Caluso 35, 10125 Torino, Italia.

E-mail:marco.pavia@unito.it

Museo Civico di Storia Naturale di Carmagnola, Via San Francesco di Sales 188, 10022 Carmagnola, Italia.

* Corresponding author: g.boano@gmail.com

(C) 2018 Marco Pavia, Giovanni Boano

Received: 1 May 2017

Accepted for publication: 12 January 2018

\section{INTRODUCTION}

Zusi et al. (1982) emphasized the importance of ornithological skeletal material and stated that one-third of bird species are not preserved in museum collections by skeletal remains and for more than one-third of the species represented in museum collections, less than ten specimens are preserved. If the species with a limited distribution range are only considered, the situation is even worse, since they represent more than $55 \%$ of the species for which no skeletons exist (Jenkinson \& Wood, 1985). The lack or scarcity of skeletal material of so many species, and in particular of rare or extinct ones can be a nearly insurmountable impediment to systematic and paleontological investigations (Olson et al., 1987). In some cases, museum curators considered the "sacrifice" of some old or poorly preserved mounted or skin specimens to remove the remaining skeletal elements to preserve the flight feathers or obtain a study skin. This was the method for obtaining the partial skeleton of Grus americana, $\mathrm{Nu}$ menius borealis, and Ciridops anna (Jenkinson \& Wood, 1985; Olson et al., 1987).

The Slender-billed Curlew (Numenius tenuirostris) is the smallest Palaearctic species of the Genus Numenius, formerly breeding in central Siberia and wintering in the Mediterranean Basin and Western Africa (del Hoyo et al., 1996). This species is classified as Critically Endangered by IUCN, and it is considered to be facing extinction as the last generally accepted sightings of the species was made in Hungary in 2001 (Oláh \& Pigniczki, 2010). Even if the Slender-billed Curlew is not rare in Museum collections as a mounted specimen or study skin (see for example Baccetti, 1995), only two skeletons of this species are preserved: one in the American Museum of Natural History (New York) and the other one in the Museum of Zoological Institute of the Russian Academy of Science (St. Petersbug) (Wood \& Schnell, 1986). Even if the inventory of skeletal specimens is quite old (is dated to 1986: Wood \& Schnell, op. cit), we are quite sure that no other Slender-billed Curlew skeleton has been prepared since then, because it is now extremely rare.

Additionally, no spread wings are known for this species, since they were prepared as standard mounted specimens or study skins. The only exceptions are a few skins with partially opened wings and a mounted speci- 
men in Spain with open wings (Corso et al., 2014). Spread wings are of crucial importance to analyse the shape, colour, and the moult of the ventral and dorsal surfaces of the wing, and all these characters are almost impossible to see in normal study-skins, even those with partially open wings. In addition, analyzing wing surfaces may be useful for solving questions related to age, taxonomy, and wing loading and is of crucial importance for the artist. For these reasons, we also decided to detach and spread a wing following the example of Capainolo et al. (2007) with Campephilus principalis.

The Slender-billed Curlew was commonly reported in the Mediterranean area in the last two centuries before its rapid decline and was probably also common during the Pleistocene and early Holocene, even if only occasionally reported as fossil (Tyrberg, 1998). As in other similar cases, this is probably due to the lack of comparative material, which does not perfectly highlight the morphological differences between the Slender-billed curlew and the similar-in-size Whimbrel (Numenius phaeopus). In fact, the fossil remains of small-sized curlew were sometimes referred uncertainly to Numenius

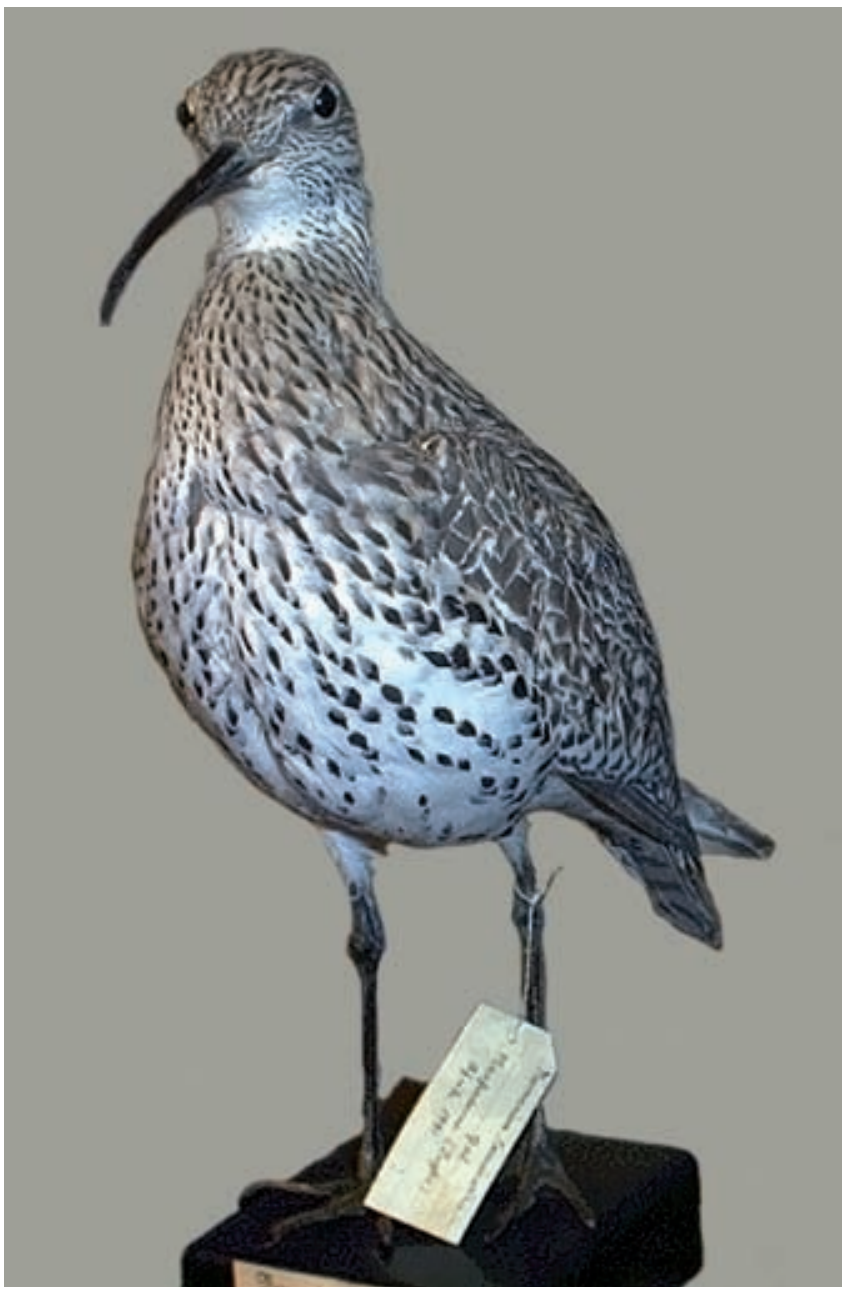

Fig. 1 - Slender-billed curlew (Numenius tenuirostris). The Italian specimen of the Noro Collection preserved at Graglia (Biella, Italy). / Chiurlottello (Numenius tenuirostris). L'esemplare italiano della collezione Noro conservato a Graglia (Biella, Italia) (see Boano, 2009). phaeopus vel N. tenuirostris (e.g. Bedetti \& Pavia, 2013; Pavia \& Insacco, 2013).

According to Baccetti (1995), in Italy there are 141 specimens of Slender-Billed Curlews, mainly preserved as mounted specimens. Most of them were collected between 1890 and 1910 . Two more specimens, one certainly captured in Italy (Manfredonia FG, 1931) (Fig. 1), were recently added to this list (Boano, 2009). This addition made a revision of the specimens preserved in some collections with a complete description, illustration, and measurements of the eight specimens of the Zoological Museum of the Torino University (MZUT), now kept in the Museo Regionale di Scienze Naturali of Torino (Table 1). Here we describe the re-preparation of a mounted specimen of Slender-billed curlew (Numenius tenuirostris) from the MZUT collection in order to obtain skeletal material and other morphological details.

\section{MATERIALS AND METHODS}

Following the suggestions of other authors (e.g. Olson et al., 1987), our idea was to obtain as much bone material as possible from one of the seven specimens of Slenderbilled Curlew from the Zoological Museum of Torino. As all the specimens were mounted, they were $\mathrm{x}$-rayed to select the specimen with the best-preserved bones (Fig. 2).

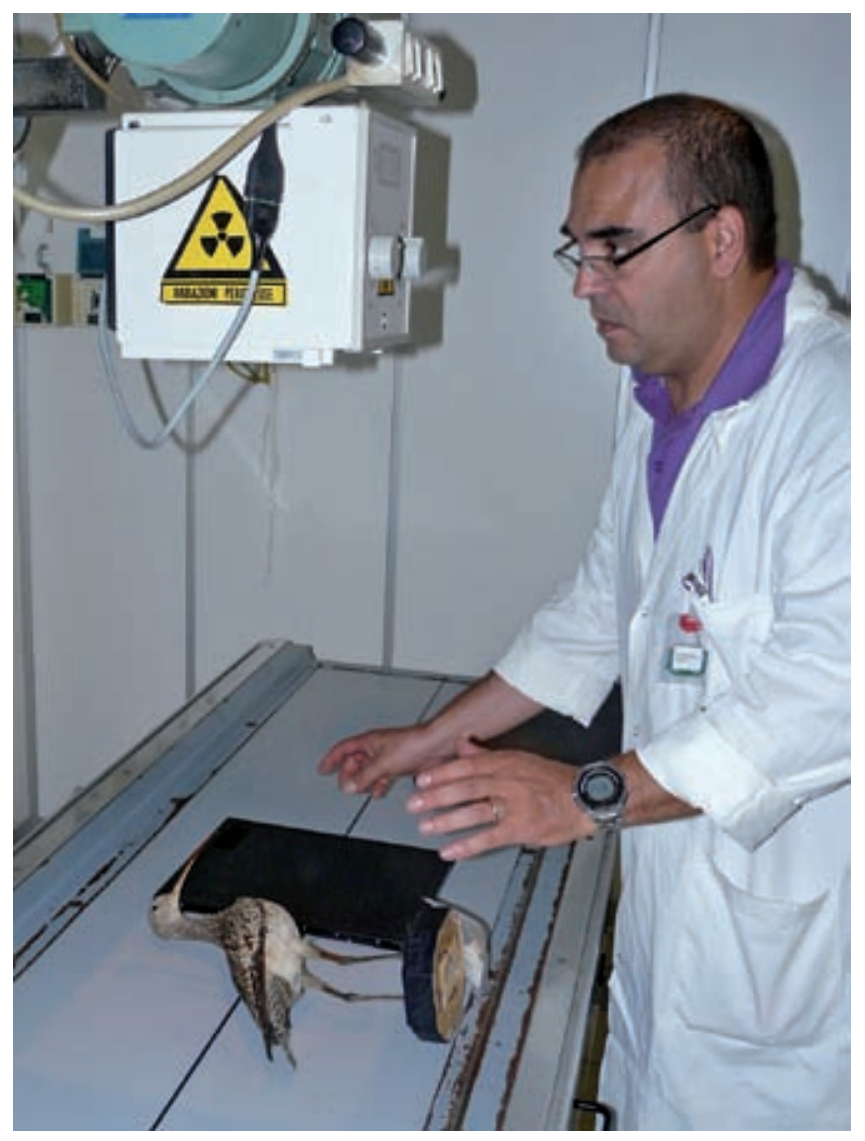

Fig. 2 - Adriano Trastu X-raying one of the specimen of Slender-billed curlew (Numenius tenuirostris) of the MZUT collection. / Radiografia RX effettuata da Adriano Trastu su di uno degli esemplari di chiurlottello (Numenius tenuirostris) della collezione MZUT. 
Tab. 1 - Original data of the specimens MZUT of Numenius tenuirostris currently stored in the Museo Regionale di Scienze Naturali di Torino. All were collected in Italy. The sex and age are listed according to the original labels. / Dati originali degli esemplari di chiurlottello (Numenius tenuirostris) delle collezioni del MZUT conservate nel Museo Regionale di Scienze Naturali di Torino. Tutti gli esemplari provengono dall'Italia. Sesso ed età sono quelli indicati sui cartellini originali.

\begin{tabular}{|l|l|l|l|l|l|l|}
\hline Catalogue $\mathbf{N}^{\circ}$ & County & Province & Locality & Date & Sex & Age \\
\hline MZUT Av 2900 & Piemonte & Torino & close to Torino & 3 Sept1828 & Female & Immature \\
\hline MZUT Av 2901 & Piemonte & Torino & close to Torino & 3 Sept1828 & Female & Immature \\
\hline MZUT Av 6521 & Piemonte & & & 1868 & Female & Immature \\
\hline MZUT Av 6522 & Piemonte & & & 1868 & Male & Immature \\
\hline MZUT Av 12247 & Toscana & Pisa & San Rossore & 1875 & Male & Adult \\
\hline MZUT Av 12248 & Toscana & Pisa & San Rossore & 1875 & Female & $?$ \\
\hline MZUT Av 12249 & Piemonte & Torino & Villastellone & 1881 & Female & Adult \\
\hline MZUT Av 19577 & Toscana & & & $1840-1870$ & $?$ & Adult \\
\hline
\end{tabular}

The choice of the specimen to be re-prepared was based on the amount of preserved bones, along with the amount of data that could be collected, with the preference for the more generic bones to be used for our purpose. We also looked at the quality of the mount and the method of preservation. Unfortunately, none of the seven specimens had a complete humerus preserved still, and the proximal end of the tibiotarsus were all broken. The selected specimen is the Slender-billed Curlew Numenius tenuirostris MZUT Av 19577 (Fig. 3), collected in Toscana (Central Italy) presumably between 1840 and 1870 ; thus it is the specimen with the least informative collecting data (Table 1) and a number of relatively well preserved bones compared to the other specimens.

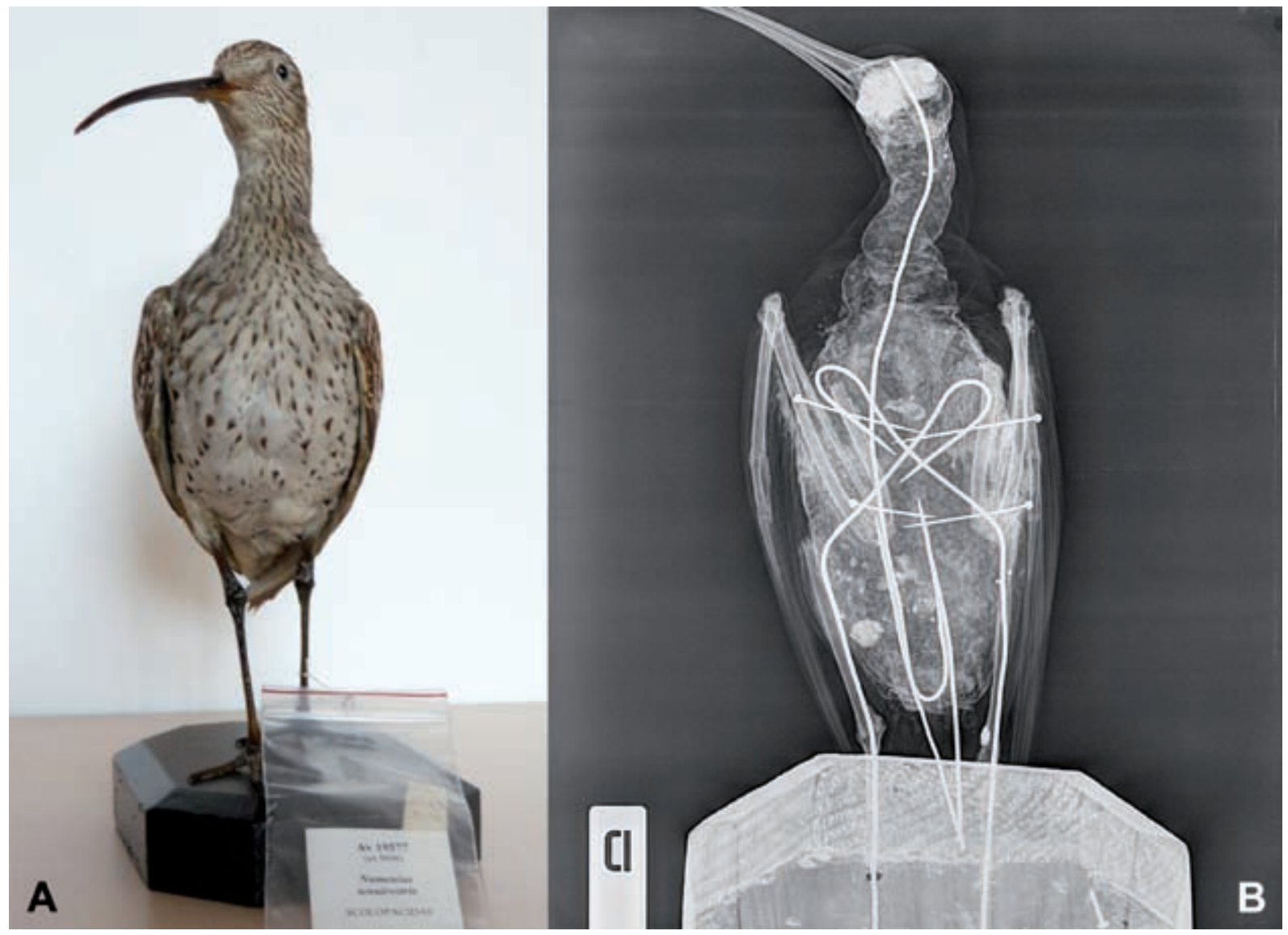

Fig. 3 - Slender-billed curlew / Chiurlottello (Numenius tenuirostris) MUZUT Av 19577. A) the specimen before preparation; B) the X-ray of the specimen, where the broken humeri and tibiotarsi are clearly visible. / A) il campione prima della preparazione; B) la radiografia dell'esemplare, dove gli omeri e i tibiotarsi rotti sono chiaramente visibili. 
The specimen was measured in detail (skull+bill: $123.7 \mathrm{~mm}$; bill: $82.3 \mathrm{~mm}$; nalospi: $71.4 \mathrm{~mm}$; bill height: $8.9 \mathrm{~mm}$; bill width: $7.7 \mathrm{~mm}$; minimal wing length: 245.0 $\mathrm{mm}$; tail: $98.0 \mathrm{~mm}$; exposed tibia: $26.0 \mathrm{~mm}$; tarsus: 67.0 $\mathrm{mm}$; foot: $42.0 \mathrm{~mm}$; medium toe: $35.5 \mathrm{~mm}$.), then the skin was relaxed in a closed container above a layer of wet sand laced with phenol to prevent mould, following Olson et al. (1987) and Capainolo et al. (2007). We monitored the relaxing process, and after eight days when the skin was judged sufficiently relaxed, we started the re-preparation process. The skin was gently opened and stuffing material and wires were removed. Then the bones were carefully removed, and the left wing was cut off to prepare it as a spread wing. The cut wing was further soaked for one day before extending and pinning it to dry in a good position.

Since the skin was surely tanned with arsenic, we kept some tissue samples and the few feathers that were lost during re-preparation for future genetic analysis to minimize unnecessary future destructive sampling.

Photographic documentation was taken for all steps of the procedure.

\section{RESULTS}

After the preparation, we obtained a study skin with one leg (Fig. 4), a spread wing (Fig. 5) likely the first spread wing of a Slender-billed Curlew preserved in a museum collection, and some skeletal elements: the skull and bones from one wing and one leg (Fig. 6). The principal measurements of the complete bones are reported in Table 2 measured according to Von den Driesch (1976).

Although the analysis of the osteological differences between Numenius tenuirostris and N. phaeopus is out of the scope of this paper, we highlight here some characteristics that were clearly visible on the cleaned skeletal elements of MZUT Av 19577. The specimen was probably a female based on the bill length (Corso et al., 2014), which

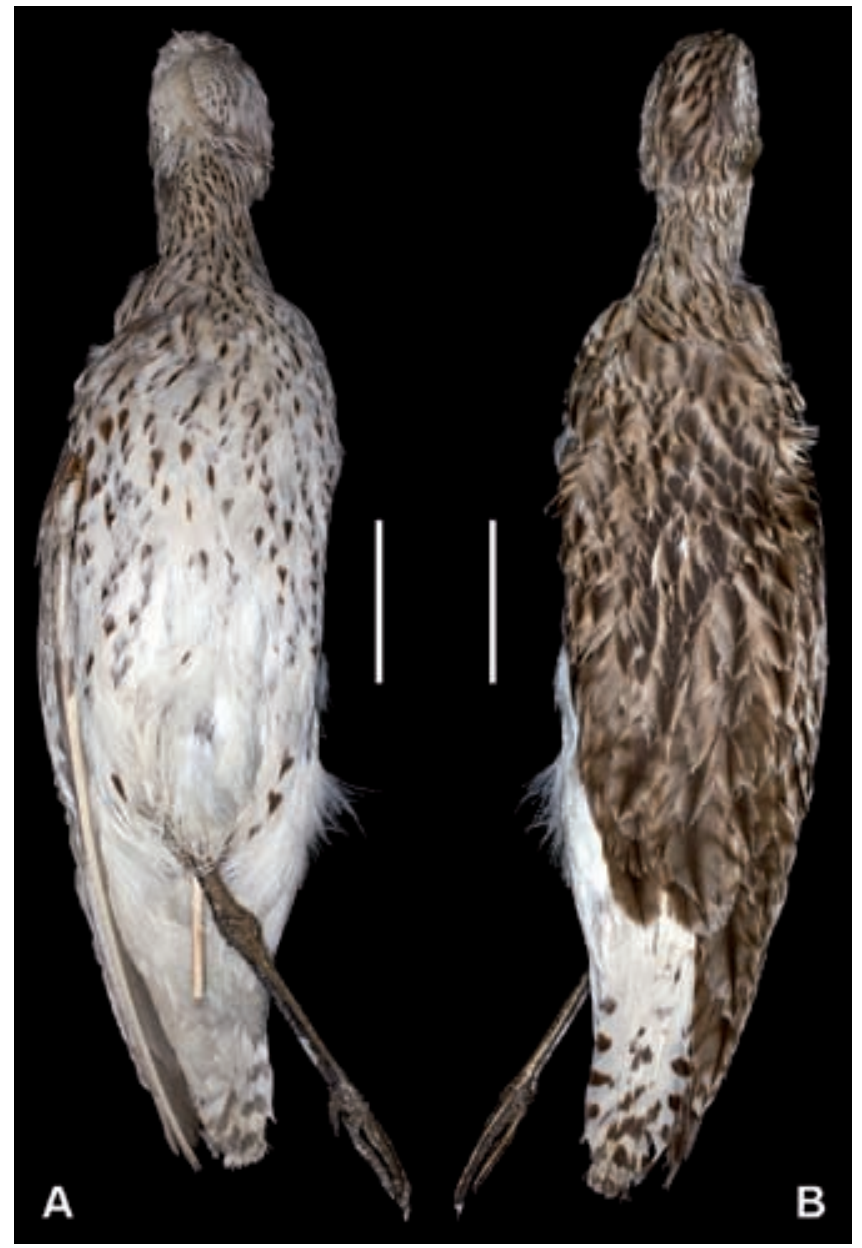

Fig. 4 - Slender-billed curlew / Chiurlottello (Numenius tenuirostris) MUZUT Av 19577. The study skin with one leg obtained after the re-preparation of the mounted specimen in ventral (A) and dorsal (B) views. The scale bars represent $5 \mathrm{~cm}$. / La pelle da studio con una zampa ottenuta dopo la nuova preparazione del campione precedentemente montato in vista ventrale (A) e dorsale (B). Le barre rappresentano $5 \mathrm{~cm}$.

Tab. 2 - Measurements (in mm) of the skeletal elements obtained from the Slender-billed curlew (Numenius tenuirostris) MZUTAv 19577. Measurements of bones that are slightly worn or damaged are given in parentheses. / Misure (in $\mathrm{mm}$ ) degli elementi scheletrici ottenuti dalla ripreparazione dell'esemplare di Chiurlottello (Numenius tenuirostris) MZUT Av 19577. Le misure di ossa consumate o danneggiate sono tra parentesi. Abbreviations / Abbreviazioni: GL) greatest length / lunghezza massima; Wp) proximal width / larghezza prossimale; Dp) proximal depth / spessore prossimale; Wd) distal width / larghezza distale; Dd) distal depth / spessore distale; Ws) smallest width of shaft / diametro minimo della diafisi.

\begin{tabular}{|l|r|r|r|r|r|r|r|}
\hline MZUT Av 19577 & GL & Wp & Dp & Wd & Dd & Ds & Ws \\
\hline Mandible & 106.5 & - & - & - & - & - & - \\
\hline Skull & 122.5 & - & - & - & - & - & - \\
\hline Humerus & - & - & - & 11.9 & 67.2 & 5.0 & 4.6 \\
\hline Radius & 85.5 & 4.3 & 3.5 & 5.6 & 3.6 & 2.4 & 2.1 \\
\hline Ulna & 89.1 & 8.8 & 7.6 & 6.1 & 7.3 & 4.3 & 3.9 \\
\hline Carpometacarpus & 47.0 & $(10.0)$ & 4.5 & 5.7 & 5.2 & 3.5 & 3.4 \\
\hline Tibiotarsus & - & - & - & 7.2 & 6.8 & 4.0 & 3.0 \\
\hline Tarsometatarsus & 64.4 & 8.7 & 7.6 & 8.2 & 6.5 & 3.1 & 2.6 \\
\hline
\end{tabular}




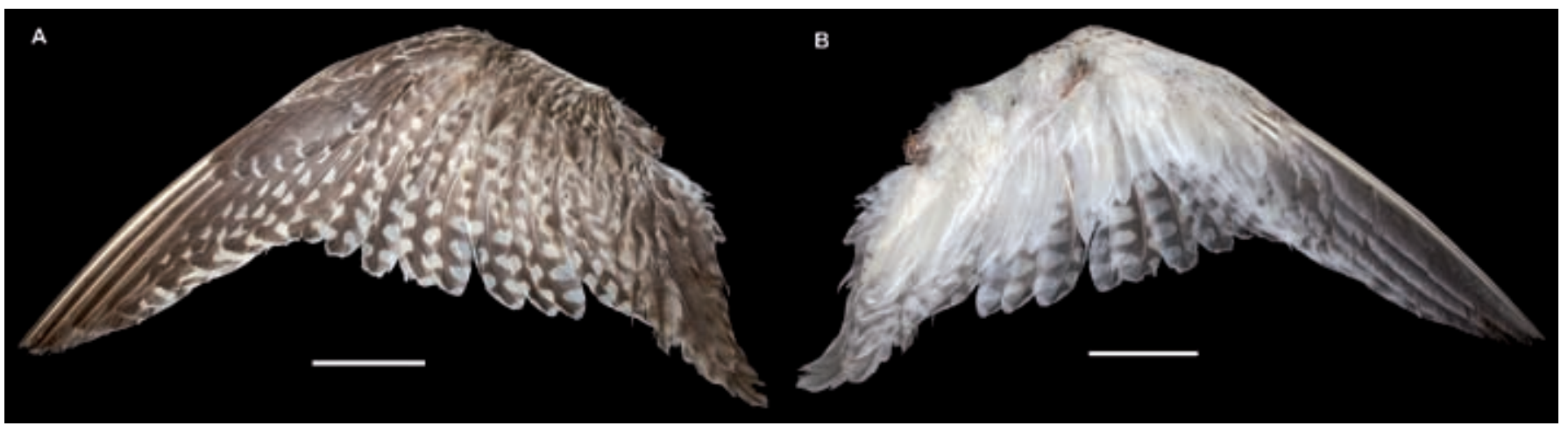

Fig. 5 - Slender-billed curlew / Chiurlottello (Numenius tenuirostris) MUZUT Av 19577. Detached and extended left wing in upper (A) and lower (B) views. The scale bars $=5 \mathrm{~cm}$. / Ala sinistra distaccata ed estesa in visione superiore $(\mathrm{A})$ e inferiore $(\mathrm{B})$. Barre $=5 \mathrm{~cm}$.

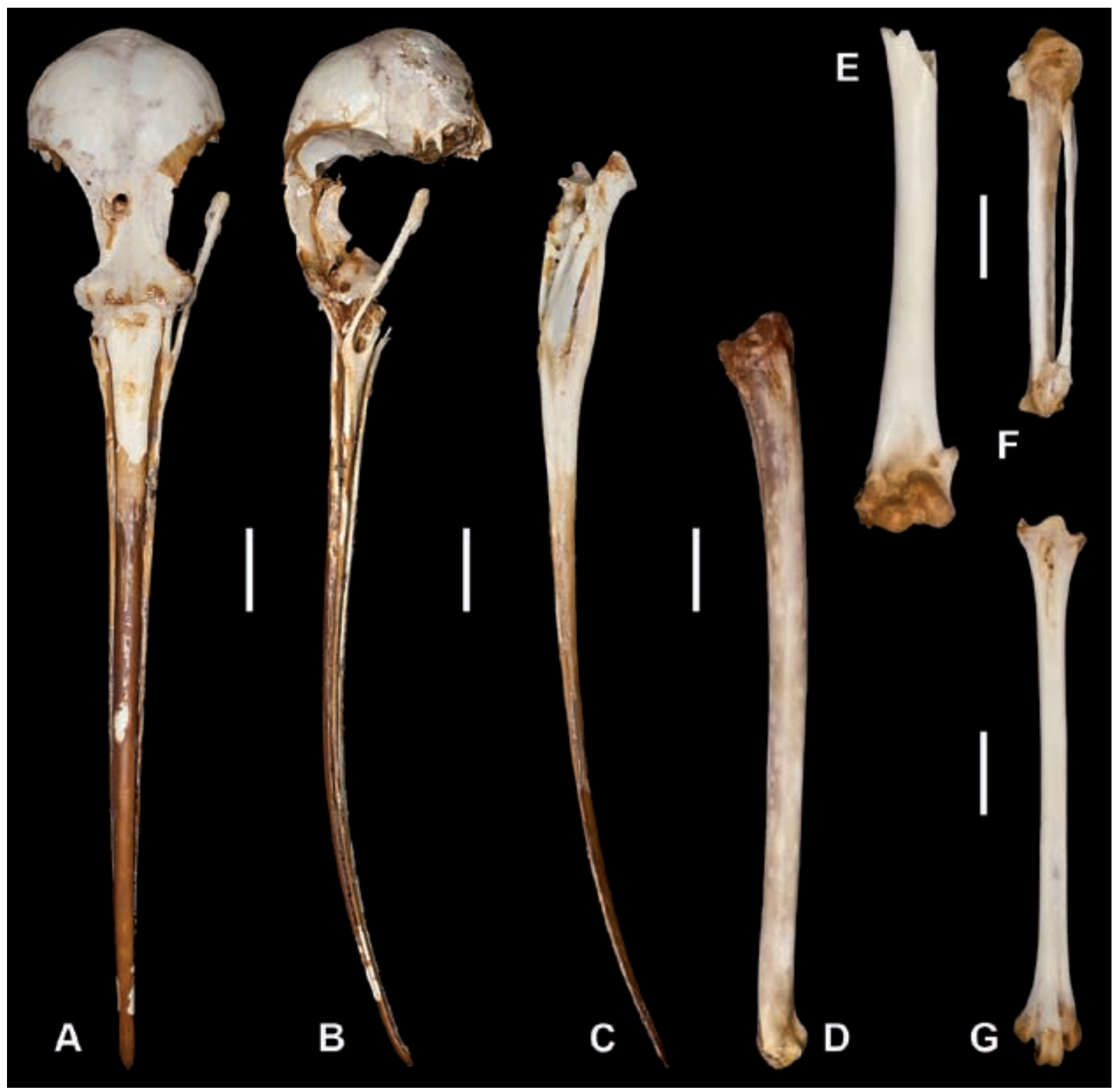

Fig. 6 - Slender-billed curlew / Chiurlottello (Numenius tenuirostris) MUZUT Av 19577. Part of the skeletal elements salvaged from the mounted specimen: cranium in dorsal (A) and left lateral (B) views; ramus of mandible in reversed right lateral view (C); right ulna in ventral view (D); left distal humerus in cranial view (E); right carpometacarpus in ventral view (F); left tarsometatarsus in dorsal view $(\mathrm{G})$. Scale bars $=1 \mathrm{~cm}$. / Parte degli elementi scheletrici recuperati dall'esemplare montato: cranio in vista dorsale (A) e laterale sinistra (B); ramus della mandibola in vista laterale destra rovesciata (C); ulna destra nella vista ventrale (D); omero distale sinistro in vista craniale $(\mathrm{E})$; carpometacarpo destro in vista ventrale $(\mathrm{F})$; tarsometatarso sinistro in vista dorsale $(\mathrm{G})$. Barre $=1 \mathrm{~cm}$. 
is also less curved and slenderer than that of Numenius phaeopus. The distal part of the humerus shows the condylus ventralis protruding very distally in $N$. phaeopus, while it is less evident in $N$. tenuirostris, since the processus supracondylaris dorsalis is also weaker in $N$. tenuirostris. The condylus dorsalis ulnaris is more evident in $N$. tenuirostris with an angular junction with the shaft that is not as continuous as in N. phaeopus. In the distal tarsometatarsus, the trochlea metatarsi III is more distally prominent in $N$. tenuirostris, where the trochlea metatarsi IV is also more proximal than the trochlea metatarsi II and not on the same line as in N. phaeopus.

The plumage characteristics observed in the MZUT specimen agree with the information given by Corso et al. (2014). In particular, those of the underwing, where it is possible to observe the typical plain pattern of the primaries and the almost completely white greater underwing primary coverts, were even whiter than shown by Corso et al. (2014, Fig. 2).

The complete specimen with all its parts is stored in the Museo Regionale di Scienze Naturali di Torino, and all parts are catalogued with the original collection number (MZUT Av 19577). This specimen, in particular the partial skeleton, could be a perfect starting point to verify the correct determination of other putative skeletons of the Slender-billed curlew, such as the two preserved in the Istituto Italiano di Paleontologia Umana of Anagni (Italy) or two others preserved in the Institut de Paléontologie Humaine (MNHN, Paris) (M Pavia, pers. observations 2003 and 2012).

Our work shows the added value a specimen, especially those with poor existing information or that are poorly preserved, can acquire with this taxidermy process. It also serves as an example of the possible potential of historical specimens from museum collections.

The improved knowledge about the osteology of the Slender-billed Curlew (Numenius tenuirostris) will help when re-analysing the fossil record of small-sized $\mathrm{Nu}-$ menius in order to establish the real fossil record of this species and acquire new information on its past distribution. It may also help in understanding the causes of its dramatic decline in the last century.

\section{Acknowledgments}

We would like to thank Ermanno de Biaggi and Elena Gavetti and Cristina Giacoma of the Museo Regionale di Scienze Naturali di Torino for putting the specimens under their care at our disposal. We also would like to thank Anna Pilone and Adriano Trastu for the opportunity to make $\mathrm{X}$-rays at the Dipartimento di Patologia Animale of the Torino University. Finally, we would like to thank Brian K. Schmidt for his critical revision, which greatly improve the text, Kelsey Horvath for the English revision, and the Editor Giuseppe Bogliani for handling the manuscript.

\section{REFERENCES}

Baccetti N., 1995 - Revisione delle catture italiane di una specie giunta all'orlo dell'estinzione: Numenius tenuirostris (Aves, Scolopacidae). Ricerche di Biologia della Selvaggina, 94: 1-20.
Bedetti C. \& Pavia M., 2013 - Early Pleistocene birds from Pirro Nord (Puglia, southern Italy). Palaeontographica, Abteilung A, Stuttgart, 298 (1-6): 31-53.

Boano G., 2009 - Tra mito e speranza: i chiurlottelli del museo di Torino. Analisi comparativa per birdwatcher che vogliono sognare. Quaderni di Birdwatching, XI (nuovo corso), 0: 32-39.

Capainolo P., Kenney S. \& Sweet P. R., 2007 - Extendedwing preparation made from a 117- year-old Ivorybilled Woodpecker (Campephilus principalis) specimen. The Auk, 124 (2): 705-709.

Corso A., Jansen J. \& Kókay S., 2014 - A review of the identification criteria and variability of the Slenderbilled Curlew. British Birds, 107: 339-370.

del Hoyo J., Elliott A. \& Sargatal J. (eds.), 1996 - Handbook of the birds of the World. Vol. 3. Hoatzin to Auks. Lynx Edicion, Barcelona.

Jenkinson M. A. \& Scott Woos D., 1985 - Avian anatomical specimens: a geographic analysis of needs. The Auk, 102: 587-599.

Oláh J. \& Pigniczki C., 2010 - Hew Hungarian record of Slender-billed Curlew (Numenius tenuirostris) in the Kiskunság (Hungary). Aquila, 116-117: 49-53.

Olson S. L., Angle J. P., Gradty F. V. \& James H. F., 1987 - A technique for salvaging anatomical material from study skins of rare or extinct birds. The Auk, 104: 510512.

Pavia M. \& Insacco G., 2013 - The fossil bird associations from the early Middle Pleistocene of the Ragusa area (S-E Sicily, Italy). Bollettino della Società Paleontologica Italiana, 52 (3): 157-165.

Tyrberg T., 1998 - Pleistocene birds of the Palearctic: a catalogue. Nuttal Ornithological Club, 27.

Von den Driesch A., 1976 - A guide to the measurement of animal bones from archaeological sites. Peabody Museum Bullettins, 1.

Wood D. S. \& Schnell G. D., 1986 - Revised World inventory of the avian skeletal specimens. American Ornithologists' Union \& Oklahoma Biological Survey.

Zusi R. L., Wood D. S. \& Jenkinson M. A., 1982 - Remarks on a world-wide inventory of avian anatomical specimens. The Auk, 99: 740-757. 